\title{
Stage R1
}

National Cancer Institute

\section{Source}

National Cancer Institute. Stage R1. NCI Thesaurus. Code C139579.

Presence of microscopic residual tumor after treatment. 